\title{
Evaluation of Some Botanicals and Entomopathogenic Fungi for the Control of Onion Thrips (Thrips tabaci L.) in West Showa, Ethiopia
}

Tadele Shiberu, Mulugeta Negeri and Thangavel Selvaraj*

Department of Plant Sciences and Horticulture, College of Agriculture and Veterinary Sciences, Ambo University, Ambo, P.O. Box 19, Ethiopia

\begin{abstract}
Onion thrips (Thrips tabaci L.) is one of the most important serious insect pests of onion (Allium cepa L.) cultivation in Ethiopia. The present study was conducted to evaluate some botanical extracts viz. Artemisia annua, Azadirachta indica, Bidens pilosa, Chrysanthemum cinerariaefolium, Cymbopogon citratus, Nicotiana tabacum, Nicotiana spp.,(local var.,), Parthenium hysterophorous, Phytolacca dodecandra, Securidaca longepedunculata and two indigenous isolates of entomopathogenic fungi (EPF) viz. Beauveria bassiana (PPRC-56) and Metarhizium anisopliae (PPRC-6) and soap detergent powder. They were examined for controlling onion thrips (Thrips tabaci L.) under field condition in Guder, Toke Kutaye district of Ethiopia from mid October 2010 to early April 2011. Diazinon $60 \%$ E.C was applied at the recommended rate of $1.8 \mathrm{l} / \mathrm{h}$ and the plot left was examined as controls. After $1^{\text {st }}$ day application of the different agents, EPF and untreated control were not significantly different. However, the results on $3^{\text {rd }}, 5^{\text {th }}$, and $7^{\text {th }}$ day after application of EPF treatments indicated that highly significant mortality. The rate of mortality in all of the treatments after $1^{\text {st }}$ day ranged from 0 to $74.75 \%$. On the other hand, botanical extracts recorded at $3^{\text {rd }}$ day of application ranged from 26.09 to $74.75 \%$ within 3 days of the higher mortality was recorded. On $5^{\text {th }}$ and $7^{\text {th }}$ day, except $B$. bassiana (PPRC-56), the mortality rate in all treatments became declined. The results indicated that insecticidal actions of all the tested agents exhibited to the ranging from 26.09 to $74.75 \%$ against onion thrips. Of the different agents, Nicotiana spp., P. dodecandra, S. Iongepedunculata and N. tabacum exhibited high mortality rate $(69.65,68.99,63.85$ and $63.56 \%$, respectively), whereas in C. cinerariaefolium, $A$. indica and $P$. hysterophorous showed intermediate mortality rate $(60.79,56.89$ and 52.06 respectively) and the rest were the lowest mortality rate. High bulb yield reduction was recorded in untreated plots but low yield reduction was observed in treated plots and control check. The treatments also showed reducing onion thrips population and also gave significant control over the treated check. This study indicated that Nicotiana spp., P. dodecandra, S. longepedunculata, N. tabacum and $B$. bassiana were significantly very effective against onion thrips under field condition at recommended rate and then confirmed the valuable rate of botanicals and EPF as components of Integrated Pest Management (IPM) practices in Ethiopia.
\end{abstract}

Keywords: Onion thrips; Thrips tabaci; Botanicals; Entomopathogenic fungi; Beauveria bassiana; Metarhizium anisopliae; Diazinon

\section{Introduction}

Allium crops are the most indispensable vegetable crops used as condiments in most Ethiopian cuisine. Among them, onion (Allium cepa L.) is one of the oldest known and an important bulbous vegetable crop grown in Ethiopia. It is used in preparation of different foods and in therapeutic medicine in the country. It has a great potential to produce every year for both local consumption and export with an average yield of 13.3 tons per hectare [1]. Toke Kutaye district of West Showa Zone, Ethiopia has high potential for onion cultivation due to availability of ample irrigated farmlands and the presence of relatively better market access as compared to other districts of West Showa Zone. Currently farmers in the study areas are growing the varieties of Adama red and Bombe red. However, both varieties are susceptible to onion thrips.

Onion thrips (Thrips tabaci, Lindman; Thysanoptera: Thripidae) is a key insect pest of onion [2]. In Ethiopia, it is an important insect pest that affect onion yield by direct feeding as well as reducing the quality and quantity by rasping the leaves and other tissues of onion crops to release the nutrients [3]. Onion fields can be destroyed by onion thrips, especially in dry seasons and are the major problem on onion crops in Ethiopia. Abate [3], and Merene [4] reported that onion bulb yield losses of 33 and 26-57\% respectively, due to onion thrips in Ethiopia. Similar studies at Upper Awash Agro Industry Enterprises revealed yield losses of 10 to $85 \%$ due to onion thrips in Ethiopia [5]. In Ethiopia, growers are typically sprayed insecticides to control onion thrips, but it is now apparent that there are widespread ecological consequences such as soil and ground water contamination, impacts on the food chain and potential health concerns. As a result, persistent chemical insecticides are now prohibited in most countries and replaced by less persistent pesticides [6]. The function of these products can only be induced by contact, and therefore, much less effective than barrier treatments [7]. These products can control thrips quite effectively [8]. The limitations with the use of synthetic insecticides have provided the impetus to look for alternatives [9].

Bio-pesticides are likely to have a great attention in the insecticide sector [10]. Botanical insecticides and entomopathogenic fungal (EPF) insecticides are highly effective, safe and ecologically acceptable in general [11]. The common trends in the past two decades towards reducing reliance on synthetic insecticides for control of insect pests in

*Corresponding author: Thangavel Selvaraj, Professor of Pathology and Microbiology, Department of Plant Sciences and Horticulture, College of Agriculture and Veterinary Sciences, Ambo University, Ambo, P.O. Box 19, Ethiopia, Tel: +251913073294; Fax: +251-112362037; E-mail: tselvaraj_1956@yahoo.com

Received December 12, 2012; Accepted January 21, 2013; Published January 26, 2013

Citation: Shiberu T, Negeri M, Selvaraj T (2013) Evaluation of Some Botanicals and Entomopathogenic Fungi for the Control of Onion Thrips (Thrips tabaci L.) in West Showa, Ethiopia. J Plant Pathol Microb 4:161 doi:10.4172/2157-7471.1000161

Copyright: @ 2013 Shiberu T, et al. This is an open-access article distributed under the terms of the Creative Commons Attribution License, which permits unrestricted use, distribution, and reproduction in any medium, provided the original author and source are credited. 
Citation: Shiberu T, Negeri M, Selvaraj T (2013) Evaluation of Some Botanicals and Entomopathogenic Fungi for the Control of Onion Thrips (Thrips tabaci L.) in West Showa, Ethiopia. J Plant Pathol Microb 4:161 doi:10.4172/2157-7471.1000161

agriculture, forestry, and human health. EPF, particularly Metarhizium anisopliae and Beauveria bassiana are attractive as bio-pesticides for use in integrated pest management, as they combine with host specificity and proven safety [12]. Biological control of pests with the use of plant extracts are not new practices, however, there is a need for science-based approaches to use a formal set of steps to investigate. The determination of the efficacy of botanical pesticides has to develop practical and low cost pest control. Moreover, biological control of insect pests with microbial agents has good since it would reduce inputs of chemical pesticides into the environment. Hence, the present study was taken to evaluate some botanicals and EPF for the control of onion thrips and also to assess the side effect of these bio-pesticides on mortality of natural enemies found in the experimental field.

\section{Materials and Methods}

\section{Description of the study area}

This study was conducted under field condition at Guder area in Toke Kutaye district of West Showa Zone, Oromia Regional State, Ethiopia. The area is located at $126 \mathrm{~km}$ west of Addis Ababa having an altitude of 1990 meter above sea level, latitude of $08^{\circ} 59^{\prime} 01.1^{\prime}$ North and longitude of $37^{\circ} 46^{\prime} 27.6^{\prime}$ East. The average annual rainfall is 1028.7 $\mathrm{mm}$ and maximum and minimum temperatures of the area $29.6^{\circ} \mathrm{C}$ and $11.8^{\circ} \mathrm{C}$, respectively [13]. The soil type is a vertisol which is suitable for onion production.

\section{Crop establishment}

Seeds of onion (Allium cepa L. var. Bombe red) were obtained from a seed agency, Ambo, Ethiopia, which was seeded on $6 \mathrm{~m}^{2}$ raised nursery bed on October $15^{\text {th }}, 2010$, and seedlings were transplanted into farmer's field on December $10^{\text {th }}, 2010$ (Figures 1 and 2A-2D).

Each plot was $3 \mathrm{~m}^{2}$ with five rows. Spaces used between blocks, plots, rows and plants were $1 \mathrm{~m}, 0.5 \mathrm{~m}, 0.4 \mathrm{~m}$ and $0.25 \mathrm{~m}$, respectively. The experimental field was irrigated twice per week for the first three weeks after transplanting and weekly thereafter. The field was fertilized with Di-ammonium phosphate (DAP) and urea at the rate of $200 \mathrm{~kg}$ and $150 \mathrm{~kg}$ per hectare, respectively. The DAP was applied during transplanting and urea was applied split into two times. The first half was applied during transplanting and the remaining half after 30 days transplanted. Other recommended agronomic practices were carried out as required.

\section{Experimental activities}

The experiment was arranged in randomized complete block design

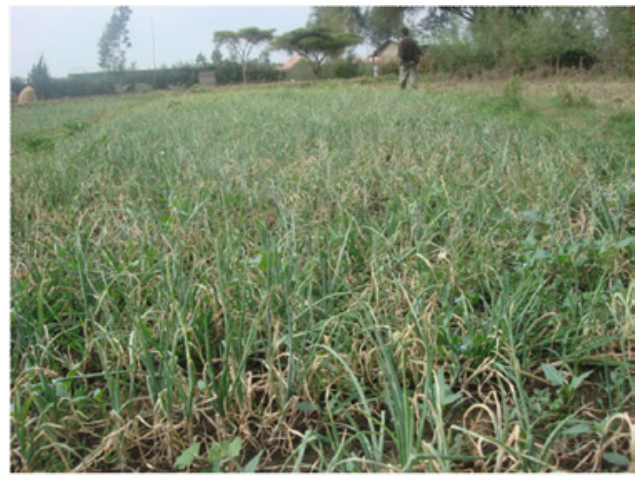

Figure 1: Experimental onion cultivated farmer's field infested with onion thrips. Scale 3.4

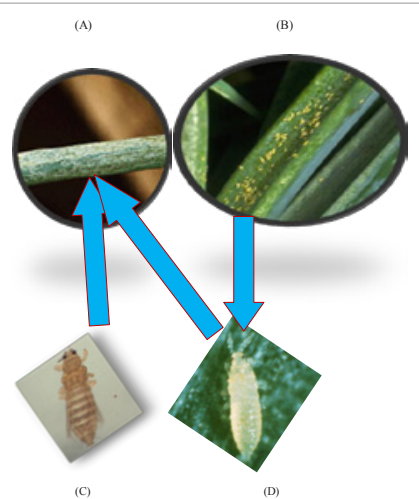

Figure 2: (A) Onion thrips infested leaf (B) Larvae of onion thrips on leaf $(C)$ Adult onion thrips (D) Larva of onion thrips. Scale 4.4.

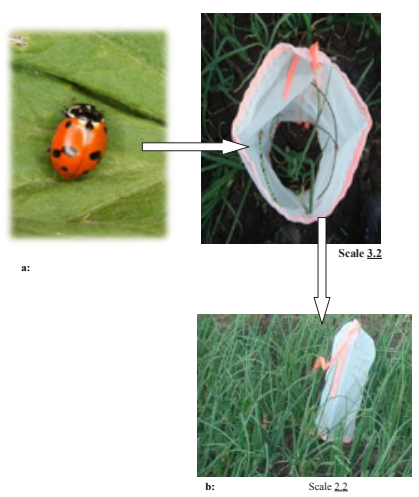

Figure 3: a) Ladybird beetle. Scale 3.2. (Adonia variegate). b) Ladybird beetles (Adonia variegate) on experimental field in tested cage. Scale 2.2.

with three replications. The experiment was made with irrigation water and transplanted Allium cepa L. var. Bombe red. Pre spray counts were recorded every week till reached economic threshold level 5 to 10 thrips per plant before treatment application [3]. After foliar treatment application of $1^{\text {st }}, 3^{\text {rd }}, 5^{\text {th }}$, and $7^{\text {th }}$ day, post spray count of number of live onion thrips adults and larvae (Figures 2B-2D) were recorded by using hand lenses and digital. The efficacy percentage was calculated by using the Abbott formula [14]:

$$
P=\frac{T a-C a}{100-C a} \times 100
$$

Where $\mathrm{P}=$ the corrected percent mortality; $\mathrm{Ta}=$ the observed percent mortality in treatment; $\mathrm{Ca}=$ the percent mortality in control

Plots were visually rated for thrips leaf damage using 0 to 8 rating scale: $0=$ no leaf damage $1=1-10 \%, 2=11-20 \%, 3=21-30 \%, 4=31-40 \%$, $5=41-50 \%, 6=51-60 \%, 7=61-80 \%$ and $8=>81 \%$. A rating of 8 reflected highly devastation by thrips (all white leaves rather than green) whereas a rating of 0 indicated zero thrips attack. A rating of four or below would be considered commercially acceptable. The reactions of the plants to the insecticides such as scorching, growth reduction, or stimulation and some abnormalities were examined and recorded. Finally upon maturity yield data were recorded.

Effect of botanicals and EPF on ladybird beetle, Adonia variegate

By nature ladybird beetles are moving from place to place. Proportion of the insect was minimal in the test plot required to bring 
them from other onion fields. To evaluate the effect of botanicals and EPF on beneficial adult ladybird beetle, Adonia variegate (Figure 3a) was collected from onion field. Then the ladybird beetles were prepared and sprayed with both botanicals and EPF fungi in the experimental plots cage. In each plot five adult beneficial insects were tested with covered cages (Figure 3b) having $50 \mathrm{~cm}$ length and $15 \mathrm{~cm}$ diameter until seven days, every $1^{\text {st }}, 3^{\text {rd }}, 5^{\text {th }}$ and $7^{\text {th }}$ day observation and data were recorded.

\section{Extraction and preparation of botanicals}

The botanicals and the rates used are given in table 1.

The most widely used forms of the botanicals were to grind the plant parts (seed, flower, leaf, stalk, root and root bark) and extracting them with water. The plant parts were grind in a mortar using a pestle to a fine consistency using a plate (corn) mill and placed into a cheese cloth bag. The cheese cloth bag was then suspended in a bucket with water added to the content of the bag. The extract from the bag was collected as it emerges from the bag. The following plants and correspondingly mentioned plant parts were used for extraction (Figure 4).

\begin{tabular}{|l|l|l|l|l|}
\hline Materials Used & Parts used & Rate/l & Rate/ha & $\begin{array}{l}\text { Amount } \\
\text { of water } \\
\text { required/ha } \\
\text { (Liters) }\end{array}$ \\
\hline Artemisia annua & & & & \\
\hline Azadirachta indica & Leaf and stalk & $10 \mathrm{~g}$ & $2 \mathrm{~kg}$ & $150-200$ \\
\hline Bidens pilosa & Seed & $25 \mathrm{~g}$ & $5 \mathrm{~kg}$ & $200-300$ \\
\hline Securidaca longepedunculata & Whole plant & $20 \mathrm{~g}$ & $3 \mathrm{~kg}$ & $200-300$ \\
\hline Cymbopogon citratus & Root bark & $10 \mathrm{~g}$ & $2 \mathrm{~kg}$ & $150-200$ \\
\hline Chrysanthemum cinerariaefolium & Leaf and stalk & $10 \mathrm{~g}$ & $2 \mathrm{~kg}$ & $150-200$ \\
\hline Nicotiana tabacum (Verginia k-10) & Leaf and stalk & $12.5 \mathrm{~g}$ & $2 \mathrm{~kg}$ & $150-200$ \\
\hline Nicotiana spp. (local variety ) & Leaf and stalk & $20 \mathrm{~g}$ & $3 . \mathrm{kg}$ & $150-200$ \\
\hline Parthenium hysterophorous & Root & $20 \mathrm{~g}$ & $3 \mathrm{~kg}$ & $150-200$ \\
\hline Phytolacca dodecandra & Seed & $10 \mathrm{~g}$ & $2 \mathrm{~kg}$ & $150-200$ \\
\hline Soap powder detergent & - & $10 \mathrm{~g}$ & $2 \mathrm{~kg}$ & $150-200$ \\
\hline Diazinon 60\% E.C & - & $5 \mathrm{ml}$ & $1.8 \mathrm{I}$ & $100-200$ \\
\hline
\end{tabular}

Table 1: The botanicals and the rates used for Extraction preparation.

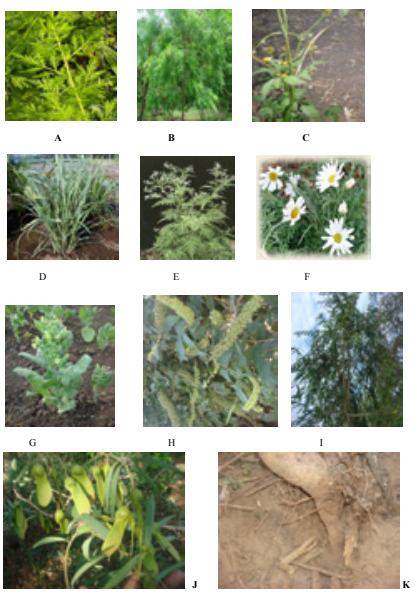

Figure 4: Botanicals used for the study: (A) Artemisia annua (wormwood) (B) Azadirachta indica (neem), (C) Bidens pilosa (spanish needle), (D) Cymbopogon citratus (lemon grass), (E) Parthenium hyeterosphorous, (F) Chrysanthemum cinerariaefolium (Pyrethrum), (G) Nicotiana tabacum (local tobacco), (H) Phytolacca dodecandra (Endod) (I, J, \& K) Securidaca longepedunculata (violet tree, pod with seeds and roots).
Artemisia annua: The matured leaves and stalks were collected from the Ambo Plant Protection Research Center, Ambo and dried under shade. $110 \mathrm{~g}$ of leaves and stalk powder were mixed with 1 liter of water, boiled for 10 minutes and then poured into 10 liters with additional water. The spray was made as soon as on onion thrips were observed in the onion field [15].

Azadirachta indica: The neem seeds were collected from Melka Werer Agricultural Research Center, Ethiopia. The seeds were grinded and then $50 \mathrm{~g}$ of neem powder was used in 2 liters of water, and extracted over night. The next day it was filtered with the help of cheese cloth and mixed with liquid soap at the rate of $1 \mathrm{ml} / \mathrm{lt}$ of extract. Then the solution was ready for sprayed on infested onion thrips [16].

Bidens pilosa: The matured whole plant was collected from Ambo area farmer's field, Ambo. One matured plant was pounded and $40 \mathrm{~g}$ was soaked in 2 liters of water over night, and then added $10 \mathrm{mg}$ of soap powder and filtered out with cheese cloth, then the solution was made ready for spray [16].

Chrysanthemum cinerariaefolium: C. cinerariaefolium var. E-185 was collected from Bokoji Research Sub-Center, Ethiopia. $50 \mathrm{~g}$ of flower powder was extracted in 10 liters of water, stirred and filtered with cheese cloth. This mixture was then sprayed on treatment plots as described by Rankin [17].

Cymbopogon citrates: The leaves and stalks were collected from Ambo area farmer's garden, Ambo, Ethiopia and dried under shade and then grinded $20 \mathrm{~g}$ of the powder added into 2 liters of water and filtered in cheese cloth and sprayed [17].

Nicotiana spp. (local var. tobacco): Tobacco leaves and stalks were collected from the gardens of farmers around Guder town, Ethiopia. The collected materials were dried under shade, $30 \mathrm{~g}$ of dried leaves and stalks were crushed and mixed with 1.5 liters of water and $10 \mathrm{mg}$ of soap flaks were added as adhesive agent. After one day, the mixed materials were filtered out and sprayed [18].

Nicotiana tabacum (Verginia k-110): N. tabacum var. verginia $\mathrm{k}-110$ leaves and stalks were prepared by mixing $250 \mathrm{~g}$ of the sample mixed with 4 liters of water and $30 \mathrm{~g}$ of soap flakes were added as adhesive agent. This mixture was boiled for 30 minutes, and the plant parts were filtered out and 16 liters of water was added to form a solution and then sprayed [18].

Parthenium hysterophorous: The matured plant was collected from Ambo town road side and urban agricultural field. $20 \mathrm{~g}$ of plant roots were taken and grounded and then soaked in one liter of water over night and $10 \mathrm{mg}$ of soap powder was added. After filtering, the solution was made ready for spray on onion thrips infested onion plants [19].

Phytolacca dodecandra: Fully grown green but unripe berries were collected from road side grown voluntary plantations at Ambo town, Ethiopia. The berries were allowed to dry in the shade for two weeks and the dried berries were crushed and stored in plastic bags at room temperature $\left(20-30^{\circ} \mathrm{C}\right)$. The powder extract was obtained by soaking in water for $24 \mathrm{~h}$ and then filtered. $150 \mathrm{~g}$ of seed powder was mixed with 15 liters of water and $10 \mathrm{mg}$ of soap powder was added and then filtered and ready for sprayed [19].

Securidaca longepedunculata: The root bark of S. longepedunculata was collected from Gendeberet District, West Showa Zone, Ethiopia. The root bark was collected from underground part of the plant, washed, grinded in mortal, and then made a paste. $50 \mathrm{~g}$ was added in 
Citation: Shiberu T, Negeri M, Selvaraj T (2013) Evaluation of Some Botanicals and Entomopathogenic Fungi for the Control of Onion Thrips (Thrips tabaci L.) in West Showa, Ethiopia. J Plant Pathol Microb 4:161 doi:10.4172/2157-7471.1000161

Page 4 of 7

5 liters of water and filtered through cheese cloth and then sprayed on infested onion plants [20].

In addition to the above mentioned botanicals, soap detergent powder and Diazinon 60\% E.C were used as a treatment and standard check, respectively. $10 \mathrm{~g}$ of soap detergent powder was added to 1000 $\mathrm{ml}$ holding jar and filled with water to dilute the soap. This liquid was placed in a spray bottle for a basic homemade insecticidal soap for spraying on onion thrips.

\section{Preparation of EPF conidial spores}

Two indigenous EPF viz. Beauveria bassiana (PPRC-6) and Metarhizium anisopliae (PPRC-56) were obtained from Ambo Plant Protection Research Center, Ambo, Ethiopia. Sabouraud Dextrose Yeast Agar (SDYA) media was used for sub-culturing of both EPF (Figures 5 and 6). The cultures were incubated at $28^{\circ} \mathrm{C}$ for 10 days in the dark. On each culture plate, spores were harvested by flooding $10 \mathrm{ml}$ of distilled sterilized water and $0.01 \%$ Tween 20 on plates. The spore suspensions were again filtered through cheese cloth and diluted (1:10) in sterile water. The suspensions were vortexed for eight minutes to avoid clumping of the spores. The conidial concentration of each isolate was adjusted to $1 \times 10^{7}$ conidia/ml using haemocytometer $[21,22]$ and then made ready for foliar application by hand sprayers.

\section{Data analysis}

Analysis of variance (ANOVA) was conducted using Statistical Analysis Software [23] and compared treatment effects. The mean comparisons were carried out using Duncan's Multiple Range Test (DMRT). Efficacy analysis was done based on data transformation to Arcsine [24]. Correlation analysis was also made to establish the relationship between bulb yield losses and infestation level. Yield loss percentage was calculated by comparing the standard check with other treatments.

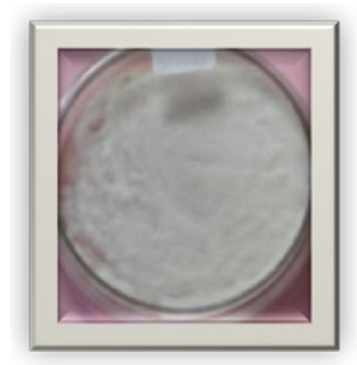

Figure 5: Beauveria bassiana culture plate.

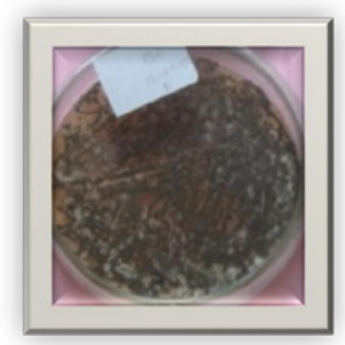

Figure 6: Metarhizium anisopliae culture plate.

$$
\text { Yieldloss }(\%)=\frac{\text { Standardcheck }- \text { each treatment }}{\text { Standardcheck }} \times 100
$$

\section{Results and Discussion}

\section{Effect of botanicals and EPF against onion thrips and impact on onion crops}

The results of the preliminary assessment of the study area found that the onion thrips infestation was high and specifically damage was increased on the crop during late February to early April. In order to reduce the infestation level of the thrips on onion through some botanicals and EPF agents under field condition was determined. Highly significant differences among the treatments were observed after application of botanicals and EPF agents and the results are depicted in tables 2,3 and figure 7. After $1^{\text {st }}$ day application of treatments, EPF and untreated control were not significantly different. The rate of mortality in all of the treatments after $1^{\text {st }}$ day ranged from 0 to $74.75 \%$. In terms of mortality some of the treatments viz. Nicotiana spp., $P$. dodecandra, $S$. longepedunculata and N. tabacum exhibited high mortality rate

\begin{tabular}{|c|c|c|}
\hline \multicolumn{3}{|c|}{ Per cent mortality of onion thrips /Days after application } \\
\hline Treatments & $1^{\text {st }}$ day & $3^{\text {rd day }}$ \\
\hline Artemisia annua & $50.46(45.26+0.79)^{\text {def }}$ & $32.49(34.45+0.61)^{d}$ \\
\hline Azadirachta indica & $63.47(52.92+0.92)^{\text {cde }}$ & $76.17(60.79+1.06)^{\mathrm{ab}}$ \\
\hline Bidens pilosa & $31.74(30.08+0.60)^{f}$ & $34.48(35.94+0.63)^{d}$ \\
\hline Securidaca longepedunculata & $78.10(58.34+1.08)^{\mathrm{bcd}}$ & $79.57(63.85+1.10)^{\mathrm{ab}}$ \\
\hline Cymbopogon citratus & $44.13(41.35+0.73)^{\text {ef }}$ & $31.41(33.41+.59) d$ \\
\hline Chrysanthemum cinerariaefolium & $62.70(52.43+0.91)^{\text {cde }}$ & $69.77(56.89+1.0)^{\mathrm{abc}}$ \\
\hline Nicotiana tabacum (Ver. k-110) & $79.19(62.98+1.10)^{\mathrm{abc}}$ & $80.10(63.56+1.11)^{\mathrm{ab}}$ \\
\hline Nicotiana spp. (local variety ) & $86.31(68.60+0.19)^{\mathrm{ab}}$ & $86.97(69.65+1.20)^{\mathrm{a}}$ \\
\hline Parthenium hysterophorous & $62.14(52.06+0.91)^{\text {cde }}$ & $40.06(38.93+0.69)^{\text {cd }}$ \\
\hline Phytolacca dodecandra & $76.9862 .22+1.07)^{\mathrm{abc}}$ & $86.37\left(68.99+1.190^{\mathrm{a}}\right.$ \\
\hline Beauveria bassiana (PPRC-6) & $0.0(0.0+0)^{9}$ & $50.78(46.18+0.79)^{\text {bcd }}$ \\
\hline Metarhizium anisopliae (PPRC-56) & $0.0(0.0+0)^{g}$ & $26.56(26.09+0.54)^{d}$ \\
\hline Soap powder detergent & $43.12(41.02+0.72)^{\mathrm{de}}$ & $31.84(33.31+0.31)^{d}$ \\
\hline Diazinon $60 \%$ E.C (standard check) & $91.58(74.75+1.28)^{a}$ & $91.27(74.75+1.27)^{\mathrm{a}}$ \\
\hline Untreated control & $0.0(0.0+0)^{g}$ & $0.0(0.0+0) \mathrm{e}$ \\
\hline MSE & $10.43(7.12)$ & $15.39(11.02)$ \\
\hline CV (\%) & 20.53(16.55) & $29.36(23.38)$ \\
\hline \multicolumn{3}{|c|}{ Days after application/ per cent of mortality } \\
\hline Treatments & $5^{\text {th }}$ day & $7^{\text {th }}$ day \\
\hline Artemisia annua & $1.81(4.49+0.31)^{\mathrm{cd}}$ & $2.31(5.08+0.15)^{c}$ \\
\hline Azadirachta indica & $60.80(51.31+0.89)^{a}$ & $55.03(47.93+0.84)^{\mathrm{ab}}$ \\
\hline Bidens pilosa & $7.30(12.16+0.27)^{\mathrm{bcd}}$ & $2.75(5.56+0.17) c$ \\
\hline Securidaca longepedunculata & $62.37(52.23+0.91)^{a}$ & $63.43(52.24+0.91)^{\mathrm{ab}}$ \\
\hline Cymbopogon citratus & $8.0(16.16+0.29)^{\mathrm{bc}}$ & $3.33(11.25+0.18) c$ \\
\hline Chrysanthemum cinerariaefolium & $59.23(50.41+0.88)^{a}$ & $56.53(48.82+0.85)^{\mathrm{ab}}$ \\
\hline Nicotiana tabacum (Ver. k-110) & $55.73(48.33+0.84)^{a}$ & $52.30(46.32+0.81)^{\mathrm{ab}}$ \\
\hline Nicotiana spp. (local variety) & $68.48(55.96+0.97)^{a}$ & $64.70(53.62+0.93)^{\mathrm{ab}}$ \\
\hline Parthenium hysterophorous & $12.77(17.28+0.36)^{\mathrm{bc}}$ & $10.94(13.25+0.34)^{c}$ \\
\hline Phytolacca dodecandra & $42.51(40.62+0.71)^{\mathrm{a}}$ & $43.97(41.51+0.72)^{b}$ \\
\hline Beauveria bassiana (PPRC-6) & $65.84(54.31+0.95)^{a}$ & $75.63(60.67+1.05)^{\mathrm{a}}$ \\
\hline Metarhizium anisopliae (PPRC-56) & $17.58(23.09+0.43)^{\mathrm{b}}$ & $13.56(16.41+0.38)^{c}$ \\
\hline Soap powder detergent & $9.50(16.10+0.31)^{\mathrm{bc}}$ & $6.90(2.38+0.27)^{c}$ \\
\hline Diazinon $60 \%$ E.C (standard check) & $71.74(55.17+0.96)^{\mathrm{a}}$ & $67.01(57.93+1.01)^{\mathrm{ab}}$ \\
\hline Untreated control & $0.0(0.00+0)^{d}$ & $0.0(0.00+0)^{c}$ \\
\hline
\end{tabular}

Note: Means with the same letter(s) are not significantly different for each other. All treatment effects were highly significant at $\mathrm{P}<0.01$ (DMRT). Figures in parentheses are Arcsin $\sqrt{\text { percent }}$ transformed value.

Table 2: Percentage mortality of onion thrips due to botanicals and EPF under field condition. 


\begin{tabular}{|l|c|c|}
\hline Treatments & $\begin{array}{c}\text { Mean leaf } \\
\text { damaged (score) }\end{array}$ & $\begin{array}{c}\text { Leaf damaged } \\
(\%)\end{array}$ \\
\hline Artemisia annua & $3.2^{\text {cd }}$ & $21-32$ \\
\hline Azadirachta indica & $2.53^{\text {efd }}$ & $21-30$ \\
\hline Bidens pilosa & $4.73^{\mathrm{b}}$ & $41-50$ \\
\hline Securidaca longepedunculata & $2.47^{\text {ef }}$ & $21-30$ \\
\hline Cymbopogon citratus & $3.73^{\mathrm{c}}$ & $31-40$ \\
\hline Chrysanthemum cinerariaefolium & $2.27^{\mathrm{fg}}$ & $11-20$ \\
\hline Nicotiana tabacum (Verginia k-10) & $1.67^{\mathrm{gh}}$ & $11-20$ \\
\hline Nicotiana spp. (local variety ) & $1.33^{\mathrm{h}}$ & $11-20$ \\
\hline Parthenium hysterophorous & $3.07^{\text {cde }}$ & $21-30$ \\
\hline Phytolacca dodecandra & $1.60^{\mathrm{h}}$ & $11-20$ \\
\hline Beauveria bassiana (PPRC-6) & $3.67^{\mathrm{c}}$ & $31-40$ \\
\hline Metarhizium anisopliae (PPRC-56) & $4.93^{\mathrm{b}}$ & $41-50$ \\
\hline Soap powder detergent & $3.20^{\text {cd }}$ & $21-30$ \\
\hline tDiazinon 60\% E.C/Check & $1.0^{\mathrm{h}}$ & $1-10$ \\
\hline Control/Untreated plot & $6.47^{\mathrm{a}}$ & $21-30$ \\
\hline MSE & 0.38 & \\
\hline CV (\%) & 12.1 & \\
\hline & & \\
\hline
\end{tabular}

Note: Means with the same letter(s) are not significantly different for each other. Al treatment effects were highly significant at $\mathrm{P}<0.01$ (DMRT).

Table 3: Percentage of leaf damaged scores due to some botanicals and EPF against onion thrips under field condition.

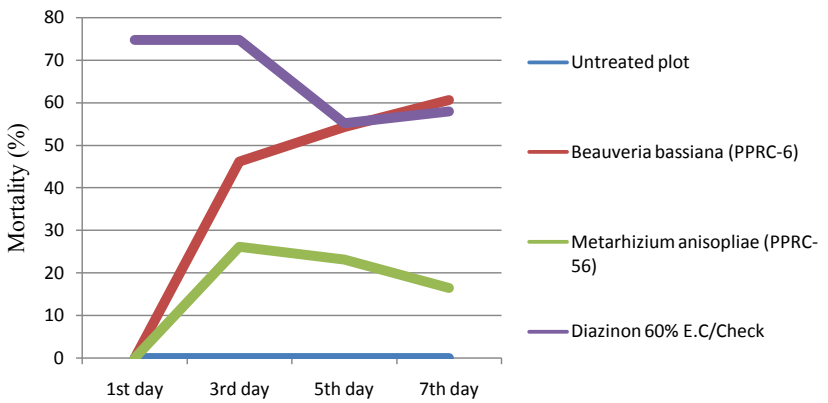

Figure 7: Mortality percentage of EPF for controlling onion thrips under field condition.

(69.65, 68.99, 63.85 and $63.56 \%$, respectively). On the other hand, the different treatments were recorded at $3^{\text {rd }}$ day of application ranged from 26.09 to $74.75 \%$. The better treatment effects were recorded after the $3^{\text {rd }}$ day of application of Nicotiana sp. (local var.) P. dodecandra, S. longepedunculata and N. tabacum (verginia k-110) A. indica and C. cinerariaefolium with mortality rates $69.65,68.99,63.85,63.56,60.79$ and $56.89 \%$, respectively. The rest of the treatments were gradually decreased after the third day of application (Table 2). In $5^{\text {th }}$ and $7^{\text {th }}$ day, the mortality rate of all treatments except B. bassiana (PPRC-56) became declined. Unlikely, B. bassiana was increased after three days. However, after treatment application of $3^{\text {rd }}, 5^{\text {th }}$, and $7^{\text {th }}$ day indicated that highly significant $(\mathrm{P}<0.01)$ differences from untreated control. Nicotiana spp. (leaf and stalk), N. tabacum (Verginia k-110, leaf and stalk), P. dodecandra (seed) and S. longepedunculata (root bark) extracts provided the best control of onion thrips. The other botanicals C. cinerariaefolium, A. indica and P. hysterophorous also provided an adequate control. In most cases, these botanicals significantly reduced thrips population densities, but not necessarily to a level that would be considered adequate. But B. pilosa, A. annua, C. citratus, and soap detergent powder were performed very low in reducing onion thrips (Table 2).
Similarly the efficacy of botanicals viz., $P$. dodecandra, $C$. cinerariaefolium, $N$. tabacum and A. indica for the controlling the onion thrips has been reported by Stoll [16] earlier. Dodia et al. [25] also mentioned that in addition to the above botanicals Cymbopogon citratus and Parthenium hysterophorous were found effect on the onion thrips. From such results, it appears that these botanicals may possess anti-feedant, repellent and insecticidal or combination of these effects to reduce the damage level caused by onion thrips [25]. According to Ayalew [26] found that the ethanol extracts of neem seed powder evaluated against onion thrips, reduced thrips population under field condition. Leaves of Bidens pilosa and soap powder were used as an insecticide for the control of leaf miners and other insects [27]. Similarly, PAN [28] indicated that B. pilosa was effective against aphid, cutworm and termites. Likely, in this study, B. pilosa was minimized the number of onion thrips population but exhibited low mortality rate percentage when compared to other treatments. S. longepedunculata showed a better performance than commonly used botanicals, $A$. indica and C. cinerariaefolium (Table 2). S. longepedunculata is a toxic plant and its root bark contains "Chamana' $e$ " which is commonly used for washing clothes as well as medicinal value against snake attack in areas where the plant is grown. Under Ethiopian condition there is a study made on the use and toxicity potential of the plant against any insect pest. In this study, this plant was found performance better than the already known botanicals, $A$. indica and $C$. cinerariaefolium (Table 2). Atawodi et al. [29] reported that the powder of root bark of this plant used as a storage grain weevil control. In this study, it was true that pyrethrum was intermediate type in its efficacy compared to other treatments, but highly significantly out of performed the untreated plot and no significant different observed as to standard check on 3rd day of treatment application. According to Purseglove [30] found that $C$. cinerariaefolium (pyrethrum) has insecticidal properties, anti-feedant or bite inhibition and contact poison properties, which is effectively used against numerous agricultural and non-agricultural insects, but harmless to human and other worm blooded animals. Casida [31] mentioned that it was a broad spectrum insecticide used to control whiteflies, aphids, mites, thrips and beetles and also reported the level of pest control is likely to be higher on field condition when properly applied. In this study, C. citratus was at $1^{\text {st }}, 3^{\text {rd }}, 5^{\text {th }}$, and $7^{\text {th }}$ day scored lesser efficacy percent against onion thrips under field condition but Stoll [16] reported that lemongrass, the whole plant extract was very effective against rice pest. In this study, P. hysterophorous root extract was minimized onion thrips at $1^{\text {st }}$ day but prolonged to decline within 7 days. Previously there was no information on effect of $P$. hysterophorous extract on thrips control but parthenium extract was reported as effective on tortoise beetle causing significant mortality on its larvae [32].

\section{Effect of EPF on onion thrips}

The effect of EPF was also evaluated on the same experimental field against onion thrips. In this study, Beauveria and Metarhizium were caused $46.18 \%$ and $26.09 \%$ mortality of onion thrips at the $3^{\text {rd }}$ day of application, respectively. It was observed that the effect of Beauveria against the onion thrips was significantly increased after 3 days whereas the effect of Metarhizium against the onion thrips was prolonged unlikely decreasing trend resulting unsatisfactory control of the pest. The control effect of $B$. bassiana was not significantly different from the standard check Diazinon $60 \%$ at $7^{\text {th }}$ day after spray (Table 2 and Figure 7). Both EPF treatments showed highly significant $(\mathrm{P}<0.01)$ difference from the untreated control. These findings are in agreement with the previous reports of Metcalf et al. [33]. They had also mentioned that $\mathrm{B}$. bassiana was most effective when used early at 
economic threshold level, before large thrips populations have built up. According to Vestergaard et al. [34] reported that the temperature is the principal factor in determining EPF efficacy. The influence of temperature on the infection process is very important. According to them, the temperature at which Metarhizium infecting adult thrips is about $23^{\circ} \mathrm{C}$ and decreases in temperature of 3 to $5^{\circ} \mathrm{C}$ increase the time to death of the insect about a day. Beauveria is used as a contact mycoinsecticide but survives a relatively short period of time when exposed on a leaf surface. The killing capacity of this fungus at $3^{\text {rd }}, 5^{\text {th }}$, and $7^{\text {th }}$ day was $46.18,54.31$ and $60.67 \%$, respectively. These results in agreement with the reports of Neil et al. [35] reported that Beauveria infection can kill the insect from 3 to 7 days, leaving a while mass of spores which can spread to other insects.

\section{Effect of botanicals and EPF on yield}

The loss of bulb yield depicted in table 4 showed that bulb yield loss attributed to onion thrips infestations. The onion crops were harvested on April $20^{\text {th }}, 2011$ and measured on the same day. There was a significant increase in super colossal yield bulbs in the treatment specifically Nicotiana spp. (local var.), P. dodecandra, S. longepedunculata, C. cinerariaefolium, $N$. tabaccum (verginia k-110) and A. indica treated plots gave high yield percentage compared to untreated plot. Rana et al. [36] also reported that the leafhopper and thrips populations were effectively managed by tobacco $5 \%$ and gave significantly higher yield against untreated control. High yield loss was recorded on treatments of B. pilosa, M. anisopliae, Soap detergent powder, C. citratus, A. annua, and P. hysterophorous, $(28.74,27.59,24.48,23.79,23.33$, and $20.34 \%$ respectively). This showed that the yield loss due to onion thrips infestation was very high and significantly $(\mathrm{P}<0.05)$ different among the treatments. The yield losses ranged from 0 to $36.44 \%$ were recorded during the study period. While the relationship between yield loss and onion thrips infestation level was attributed to reduction of yield significantly $(\mathrm{P}<0.05)$ and positive correlation $(\mathrm{r}=0.97)$ between yield reduction and leaf area damage (Figures 8 and 9 ). This means that as infestation level increased the yield loss becomes increased (Figure 8). This indicated that the yield loss due to onion thrips without any control mechanism at Gudar area, West Showa zone, Ethiopia under

\begin{tabular}{|l|l|l|l|l|}
\hline S.N & Treatments & $\begin{array}{l}\text { Mean yield/ } \\
\text { plot }(\mathrm{kg})\end{array}$ & $\begin{array}{l}\text { Mean } \\
\text { Yield/ha }(\mathrm{kg})\end{array}$ & $\begin{array}{l}\% \text { yield } \\
\text { loss }\end{array}$ \\
\hline 1 & Artemisia annua & $6.7 \mathrm{bcd}$ & 22230 & 23.33 \\
\hline 2 & Azadirachta indica & $7.6 \mathrm{abc}$ & 25330 & 12.64 \\
\hline 3 & Bidens pilosa & $6.2 \mathrm{bcd}$ & 20670 & 28.74 \\
\hline 4 & Securidaca longepedunculata & $8.0 \mathrm{ab}$ & 26670 & 8.05 \\
\hline 5 & Cymbopogon citratus & $6.6 \mathrm{bcd}$ & 22100 & 23.79 \\
\hline 6 & Chrysanthemum cinerariaefolium & $7.9 \mathrm{ab}$ & 26230 & 9.54 \\
\hline 7 & Nicotiana tabacum (Verginia k-110) & $7.7 \mathrm{abc}$ & 25870 & 11.15 \\
\hline 8 & Nicotiana spp. (loca tobacco) & $.5 \mathrm{ab}$ & 28330 & 2.30 \\
\hline 9 & Parthenium hysterophorous & $6.9 \mathrm{abc}$ & 23100 & 20.34 \\
\hline 10 & Phytolacca dodecandra & $8.2 \mathrm{ab}$ & 27230 & 6.09 \\
\hline 11 & Beauveria bassiana (PPRC-6) & $7.0 \mathrm{abc}$ & 23330 & 19.54 \\
\hline 12 & Metarhizium anisopliae (PPRC-56) & $6.3 \mathrm{bcd}$ & 21000 & 27.59 \\
\hline 13 & Soap detergent powder & $6.6 \mathrm{bcd}$ & 21900 & 24.48 \\
\hline 14 & Diazinon 60\% E.C/Check & $8.7 \mathrm{a}$ & 29000 & ---- \\
\hline 15 & Untreated control & $5.5 \mathrm{~d}$ & 18430 & 36.44 \\
\hline MSE & & 1.00 & & \\
\hline CV (\%) & & 13.73 & & \\
\hline
\end{tabular}

Note: Means with the same letter(s) are not significantly different for each other. All treatment effects were significant at $\mathrm{P}<0.05$ (DMRT)

Table 4: Mean yield and onion bulb yield loss treated with botanicals and EPF against onion thrips.

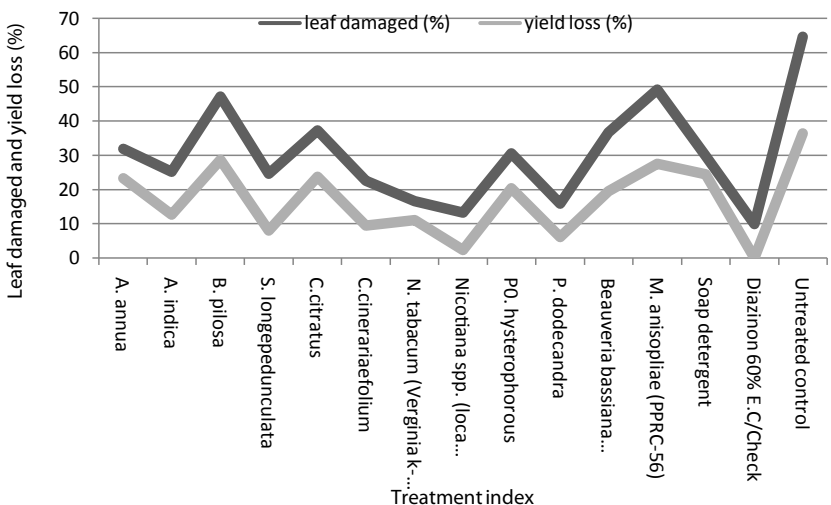

Figure 8: Relationship between leaf areas damaged and yield loss due to onion thrips infestation.

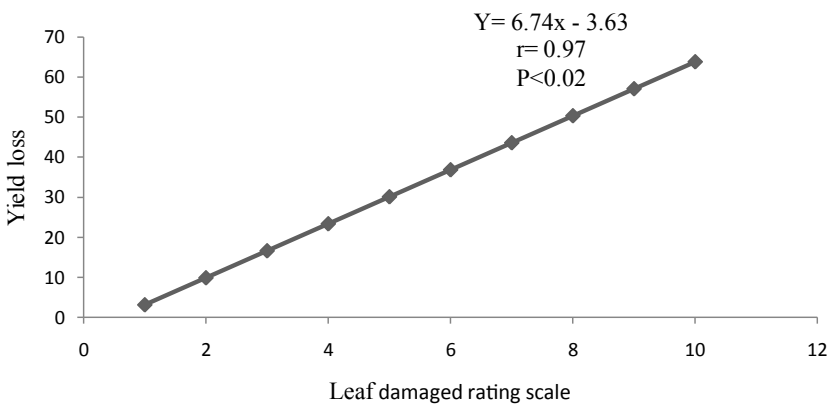

Figure 9: Estimated linear relationship between mean leaf areas damaged and yield loss due to onion thrips infestation.

field condition (Table 4). Similarly, Merene [4] suggested that onion yield loss due to onion thrips recorded $26-57 \%$ in Showa Robit area, Ethiopia.

\section{Adult ladybird beetles mortality}

Observation on predatory insect showed the presence of ladybird beetles on experimental field was found. All of the botanicals and the EPF did not affect the adult ladybird beetles in the experimental field. Dodia et al. [25] reported that nicotine is not selective insecticide and is highly toxic to a range of species including predatory insects. However, this study which was in agreement with the findings of Diraviam and Viraktamath [37] mentioned nicotine is a safer insecticide for higher animals and safer to Curinus coeruleus and other predators. Saxena [38] reported that $A$. indica is harmless to ladybird beetles that consume aphids and wasps that act as parasites on various crop pests. Artemisia spp. (leaf and stalk extract), C. citratus, B. pilosa, and C. cinerariaefolium were found to be friendly to the existing nontarget organisms whereas recent studies showed that pyrethrin based chemical products are harmful to natural enemies, fish and crustaceans and pose environmental risks [28]. In this study, percent reductions of ladybird beetle populations were observed in standard check plots. This indicated that Diazinon 60\% E.C had its side effect on ladybird beetles to some extent.

\section{Conclusions}

This study clearly indicated that the application of some botanicals based on formulation of aqua water and powder extracts were effectively control onion thrips infesting onion crops. Among tested botanicals 
Citation: Shiberu T, Negeri M, Selvaraj T (2013) Evaluation of Some Botanicals and Entomopathogenic Fungi for the Control of Onion Thrips (Thrips tabaci L.) in West Showa, Ethiopia. J Plant Pathol Microb 4:161 doi:10.4172/2157-7471.1000161

and EPF, Nicotiana spp. (local tobacco), N. tabacum (Verginia k-110) $P$. dodecandra, S. longepedunculata, and B. bassiana were significantly very effective against onion thrips after $3^{\text {rd }}$ day and followed by C. cinerariaefolium, A. indica and P. hysterophorous under field condition at recommended rate and then confirmed the valuable rate of botanicals and EPF as components of Integrated Pest Management (IPM) practices in Ethiopia. Further study on development of natural plants for the control of onion thrips, shelf life of the botanical extracts, frequency and the rate of application to be needed for the further investigation.

\section{Acknowledgements}

I am greatly indebted to my advisors Dr. Mulugeta Negeri and Prof. Thangavel Selvaraj for their invaluable professional help initiatives and encouragement This research work also could have been realized without the consistent support of the whole staff of Ambo Plant Protection Research Center (APPRC) and the Department of Plant Sciences of Ambo University, Ambo, Ethiopia.

\section{References}

1. CSA (2001) Report of Federal Democratic Republic of Ethiopia, Statistical Report on Socio-Economic Characteristics of the Population in Agricultural Households, Land Use, Area and Production of Crops. Addis Ababa, Ethiopia.

2. Alston DG, Drost D (2008) Onion thrips (Thrips tabaci), Utah Pests, Fact sheet, Utah State University, Utah.

3. Abate T (1985) Vegetable Crops Pest Management In: (Eds.) W Godfrey W Bereke TT Proceedings of the first Ethiopian Horticultural Workshop, Addis Ababa, Ethiopia.

4. Merene $Y$ (2005) Study on Population ecology and yield loss of onion thrips (Thrips tabaci) on onion in Showa Robit district of Amahara region. M.Sc. Thesis, Addis Ababa University, Ethiopia.

5. Bekele E, Azerefegne F, Abate T (2006) Facilitating the implementation and adoption of IPM in Ethiopia. Proceedings of a Planning Workshop, ASAI/EARO, Nazerath, Ethiopia.

6. British Columbia (2006) Thrips biology and control, Columbia, UK.

7. Brader $L$ (1988) Control of grasshopper and migratory locusts. Proceedings of the British Crop Protection Conference - Pests and diseases.

8. Jensen L, Simko B (2001) Alternative Methods for Controlling Onion Thrips (Thrips tabaci) in Spanish Onions. Malheur County Extension Service, Clint Shock and Lamont, Saunders, Malheur Experiment Station, Oregon State University, Ontario.

9. Henderson L (2001) Alien weeds and Invasive plants. Plant Protection Research Institute Handbook, Pretoria, South Africa.

10. Copping LG, Menn JJ (2000) Biopesticides: a review of their action, application and efficacy. Pest Management Science 56: 651-676.

11. Nathan SS, Chung PG, Murugan K (2004) Effect of botanical insecticides and bacterial toxins on the gut enzyme of the rice leaffolder, Cnaphalocrocis medinalis. Entomology 32: 433-443.

12. Bateman RP, Carey M, Moore D, Prior C (1993) The Enhanced infectivity of Metarhizium flavoviride in oil formulation to desert locusts at low humidities. Ann Appl Biol 122: 145-152.

13. Planning and Economic Development Office (1997) Zonal Atlas of West Showa, Ethiopia.

14. Abbott WS (1987) A method of computing the effectiveness of an insecticide 1925. J Am Mosq Control Assoc 3: 302-303.

15. Olkowskl W, Olkowskl H (1991) New botanical pesticides from the Meleaceae. Least toxic pest management in China bio integral resource center, Berkely, USA.

16. Stoll G (2000) Natural crop protection in the Tropics: Letting information come to life. Hohberg, Germany.

17. Rankin J (1985) ABCs of insect pests lecture notes. Solusi College, Bulawayo, Zimbabwe.
18. Lowell F (1998) Producing food without pesticides. Local solutions to crop pest control in West Africa. Dakar, Senegal.

19. Berger A (1995) Endod plant, Phytolacca dodecandra, and its application in Bilharziosis control Program, Kitwe, Zambia. Natural Plants Products as Pesticides. Proceedings of the First National Symposium in Zambia, Lutsaka, Zambia.

20. Research Council (NRC) (1992) Neem, A tree for solving Global problems Report of Ad hoc panel of the Board on Science and Technology for International Development, National Research Council, National Academy press, Washington, DC, USA.

21. Cecil HL, Lomer CJ (1996) Notes on Insect pathogens. In: LUBILOSA Technical Bulletins.

22. Senishaw A, Emiru S, Dawit A (2003) Evaluation of Ethiopian isolates of entomopathogenic fungi as a potential biological control agents of the Desert Locust. Pest management Journal of Ethiopia 7: 1-9.

23. SAS Institute (1999) The SAS system for windows, version 8.0. SAS, Institute, Cary, NC.

24. Gomez KA, Gomez AA (1984) Statistical procedures for Agricultural Research, (2ndedn), John Wiley and Sons, Inc. New York, USA

25. Dodia DA, Patel IS, Patel GM (2008) Botanical pesticides for Pest Management, 354

26. Ayalew G (2005) Comparison among some botanicals and synthetic insecticides for the control of onion thrips, (Thrips tabaci, Lind.) (Thysanoptera: Thripidae) Proceedings of the $13^{\text {th }}$ Annual Conference of the Crop Protection Society of Ethiopia (CPSE), Addis Ababa, Ethiopia.

27. PROTA (2004) Vegetables: Plant Resources of Tropical Africa, Wageningen, Netherlands.

28. PAN (2008) How to grow crops without endosulfan: Field guide to non-chemical Pest Management in banana, cabbage and other crucifers, cassava, citrus, coffee, corn, cotton and other fiber crops, cowpea, eggplant, forage crops, forest trees, garlic, lettuce, mango, mungbean, onion, ornamentals, peanut, pepper, pigeon pea, oil crops, ornamentals, potato, rice, sesame, sorghum, soybean, squash and other cucurbits, string bean, sweet potato, tea, tomato, and wheat production. Pesticide Action Net work (PAN), Hamburg,Germany.

29. Atawodi SE, Bulus T, Ibrahim S, Ameh DA, Nok AJ, et al. (2003) In vitro trypanocidal effect of methanolic extract of some Nigerian savannah plants. African Journal of Biotechnology 2: 317-321.

30. Purseglove JW (1994) Tropical Crops of Dicotyledons. Vol. 1 and 2. Longman Group Limited, England.

31. Casida JE (1973) Pyrethrum: the Natural insecticide, Academic press, New York, U.S.A.

32. Oudhia P (2000) Onion trips, Insect Environment 4: 154.

33. Metcalf CL, Flint WP, Metcalf RL (1962) Destructive and useful insects: Their habit and control, 4th (ed.), McGraw-Hill Book Co., New York.

34. Vestergaard S, Butt TM, Gillespie AT, Schreiter G, Eilenberg J (1995) Pathogenecity of the hyphomycete fungi, Verticillum lecanii and M. anisopliae to the western flower thrips, Frankliniella occidentalis. Biocontrol Science and Technology 5: 185-192.

35. Helyer N, Brown K, Cattlin ND (2004) Book Review - A Color Handbook of Biological Control in Plant Protection. Timber Press, USA.

36. Rana Cl, Bhatt NJ, Patel GM (2005) National Symposium on Stress Management, 11-13 April 2005 held at S.K. Nagar, India.

37. Diraviam C, Virktamath A (1993) Onion thrips and its control measures. Journa of Entomology 18: 77-79.

38. Saxena RC (1987) Insecticides from plants. In: Eds. Amaan JT, Philogene BJR Morand P, ACS Symposium Series, India. 